\section{Introduction: time, temporality and timescapes in administration and policy}

\section{Michael Howlett}

Simon Fraser University, Canada

\section{Klaus H. Goetz}

LMU Munich, Germany
International Review of Administrative Sciences 2014, Vol. 80(3) 477-492

(C) The Author(s) 2014 Reprints and permissions: sagepub.co.uk/journalsPermissions.nav DOI: I0.I |77/00208523 |45432 I0 ras.sagepub.com

\begin{abstract}
This article surveys time, temporality and timescapes in the study of public administration and public policy. While references to temporal categories, such as timing, sequence, speed, duration, time budgets, time limits or time horizons, are ubiquitous in political science, there are few systematic treatments of time in administration and policy-making. The special issue which this article introduces focuses on analyses that seek to explain policy development over time; the link between time and power; and the role that visualisation may play in helping to understand change over time. Taken together, the papers seek to advance the debate by I. exploring different facets of time and how they affect government and public policy; 2. paying attention to time as an institution and a resource; 3 . discussing the temporal features of politics and administration, such as, e.g., term limits, and of public policy-making, such as policy cycles or policy horizons; 4. exploring time from both diachronic-historical and synchronic perspectives; 5 . debating the status of time in different theoretical traditions in political and policy analysis; and 6. examining time from a methodological standpoint.
\end{abstract}

\title{
Keywords
}

administrative science, administrative theory, policymaking, Public, Administration, Public management

\section{The Resurgence of Time as a Political Variable}

Time has always been an issue for students of administration and public policy and - often implicit - considerations of temporality permeate the field (Elchardus 1988;

\section{Corresponding author:}

Klaus H. Goetz, Chair of Political Systems and European Integration, Ludwig-Maximilians-Universität (LMU) München, Oettingenstraße 67, München, 80538, Germany.

Email: goetz.Imu@gmail.com 
Nowotny 1992). However, over the past half century, studies have tended to focus on the synchronic rather than diachronic elements of governmental life and few have sought to grapple with temporality in as sophisticated a way as they have with spatial issues. While the methods and epistemological issues associated with spatial analyses - such as cross-national or cross-sectoral comparisons - are well laid out and explored, the impact of time is much less well established (Thelen, 2000; Stone 1999). For example, only few journals - Time \& Society or the Journal of Policy History - specifically address the subject and much behavioural research continues to be undertaken in a largely ahistorical or an atemporal way.

This situation is beginning to change as the impact of time at all levels of government and policy-making has begun to receive more detailed treatment. Pierson's Politics in Time (2004) stands out as a landmark work applying sociological insights to political phenomena, while Pollitt's Time, Policy, Management (2008) did the same for public management and public administration. The special issue of $I R A S$ which this article introduces, continues this work, examining temporality and temporal variables in politics, administration and policy.

Of the three key concepts, the term most familiar to political scientists will be political time, which has been the central focus of work such as Skowronek's (1993, 2008) on the American presidency. It generally refers to the specific historical-temporal location in which a phenomenon, such as a presidency or a public policy, exists and highlights the significance of effects such as policy legacies, sequencing and trajectories on current political actors. As Goetz and MayerSahling (2009) point out, however, this characteristic of existing and operating within a specific temporal location may be better understood as constituting temporality or historical time. Political time, then, can be reserved to refer to the very diverse range of rules, norms, conventions and understandings that serve as a resource and constraint for political institutions and actors regardless of their spatio-temporal location and affect many aspects of political and policy-making behaviour, such as the timing of decision-making and the processes of attempting to make public policies.

The idea of a timescape, developed by the sociologist Barbara Adam (1998) and defined as "a cluster of temporal features" (Adam 2004: 143), is a broader term encompassing both historical and political time. The key elements of a complete timescape, in Adam's view, include time-frames, temporality, timing, tempo, duration, sequence and temporal modalities (past, present, future) (Adam 2008). The timescape includes both time-related rules and temporal regularities.

The articles in this special issue address conceptual, methodological and epistemological issues related to time, government and public policy. Questions include the objective versus subjective construction of timescapes; how the notion of a timescape can be operationalized; what are the drivers influencing different kinds of administrative and policy change; and studies of specific terms and concepts associated with temporal research in administration and policy-making, such as duration, synchronicity, time pressures or time games. Innovative graphical and 
statistical methods for analyzing time processes and sequences in political, administrative and policy activities are also described and discussed.

\section{Explaining Patterns of Change over Time}

To explain change is one of the most fascinating challenges for any scientific enterprise. To explain social, political and policy changes, the social sciences (sociology, economics, political science, organization theory, public policy, public administration and management, and others) have borrowed theories, concepts and metaphors from other disciplines, especially from biology, psychology, system theory or palaeontology (see Gersick 1991; Eldridge and Gould 1972).

Although most policy studies focus on changes which occur in government actions over time, the need to examine carefully the often implicit theories of history behind identified patterns of policy development has only been recently recognized (Mahoney and Rueschemeyer, 2003; Saldana, 2003; Pierson, 2004). Sociologists and others at the onset of the 1990s turned to this historical question and generated an excellent corpus of conceptual and methodological work on the subject (Somers, 1996; Abbott, 2001); however, these insights are only now slowly penetrating into concepts and methods used in the policy sciences.

Summarizing this literature, Howlett and Rayner (2006) noted four major approaches to dealing with change over time in the social sciences.

\section{Ahistoric Stochasticism: General Linear Reality Models}

First, for many years, policy studies, and especially formal policy analysis, tended to proceed along the unspecified and implicit assumption that policy-making followed the precepts of what Andrew Abbott has termed a 'general linear reality' (Abbott, 1988). That is, that policy causes and effects could be ascertained empirically and a general set of social forces was seen to drive policy-making, with individual deviations from deterministic outcomes existing as 'noise' or random error (Aminzade, 1992; Griffin, 1992; Stinchcombe, 1968). Outcomes from such processes, such as policy decisions, were seen as the realization of stochastic processes, in which some underlying process with certain kinds of parameters 'determined' a result. In this 'general linear model', as Abbott has termed it, there is an implicit notion that history, per se, does not matter. That is, time is thought of as a discrete, infinitely divisible entity and 'history' is simply the assemblage of 'moments' on a temporal continuum. Which time period is chosen for analysis is immaterial as each outcome is more or less precisely determined at that moment by the existing configuration of variables. As Abbott put it, in this model, 'the social world is made up of fixed, given entities with variable properties' - cases and variables - in which outcomes consist of 'the succession of the values of a dependent property or properties over time' (Abbott, 1990).

In most social sciences, including policy science, this general conception of the ahistorical temporality of social processes has recently been challenged by 
investigators who have argued that 'sequence matters'. The determination of policy outcomes is not deterministic, in a stochastic sense, but much more contingent than previously assumed, with the sources of contingency being not merely individual actions in a given environment, but also more structural factors such as historical timing or the 'ordering' of policy-relevant events (Pierson, 2000a, 2000b, 2004; Abbott, 1990).

This emphasis on structured sequencing is a significant aspect of many recent neo-institutional approaches to the study of public policy-making (Steinmo et al., 1992; Hall and Taylor, 1996; Kato, 1996). However, the basic model of historical sequencing found to date in many neo-institutionalist studies has tended to focus only upon a single alternative model of historical processes - path dependency that is only one of several possible alternatives to the stochastic model. Most neoinstitutional studies have generally not considered the alternative possibilities and models which exist (Thelen, 2003; Lieberman, 2001) and, more surprisingly, whether or not the specific attributes of this model in fact fit the reality of most policy-making situations (Kay, 2005; Greener, 2005).

\section{Historical Narratives: Inevitable Sequence Models}

While path dependency may have emerged in recent neo-institutional accounts of policy-making as a serious competitor to the 'general linear model', in general in the social sciences, the principal alternative to the stochastic model of historical reality has been one which is much more profoundly historical in nature, but often equally un-reflective of its conceptual foundations. This is the reading of history as a causal narrative, a model and methodology prevalent in academic History departments and many other areas of social, cultural and political studies (Abbott, 1992; Stinchcombe, 1968 pp. 101-129). In this model, an entire sequence of events is read, retroactively, as a single entity. The challenge for the analyst is to uncover the 'plot' or 'narrative' which can 'explain' the development of the process from start to finish, or 'birth' to 'death' (Abbott, 1990). In this view, 'causality' is much more complicated than usually assumed in the stochastic model, in that the sequencing of events is highly significant in terms of gauging the effects of causative agents or variables. At one point in a narrative story, for example, the presence or absence of a certain variable may have one effect, while latter on it may have none, or a different one altogether. Recent work in the social sciences by authors such as Czarniawska, Abbott, and others has attempted to develop the outlines of more formal models of narratives, specifying the key assumptions of different narrative models and suggesting their utility and disutilities (Abbott, 1992; Czarniawska, 1998; Ospina and Dodge, 2005).

Abbott specified three major 'story properties' which are methodologically significant in narrative analysis. These are, 1. enchainment - or the 'narrative analogue of causality', in which it is assumed that there are links between one point in the narrative and another; 2 order - in which the narrative must proceed in a strict sequence if the observed outcome is to be explained; and 3. convergence - in which a narrative sequence might achieve a 'steady state'; a special case allowing 
stochastic analysis to be an appropriate and effective tool for analyzing developments occurring within a narrative chain (Abbott, 1992).

Abbott has also set out some of the major problems which face this kind of analysis. These include problems establishing 'endpoints' in the analysis (for example, when the 'birth' and 'death' of a phenomenon are not easily identified); problems of multiple overlapping and intersecting 'plots' which can make a central narrative storyline difficult to discern; and problems with too many characters obscuring the plotlines of a story (Abbott, 1992). All of these problems, of course, emphasize the significance for this model of the role played by the analyst as interpreter of events, who may by force of circumstances choose to simplify a story in order to reveal more clearly its fundamental plot, but who does so at the risk of imposing their own interpretation of events on history (Buthe, 2002).

The question of validating narrative interpretations has long been an issue in the hermeneutic tradition (Gadamer, 1989; Ihde, 1974). When postmodern social theory embraced its 'literary turn', for example, a development that overlapped with, but has remained distinct from, the narrative interests of historians, it drew on this rich tradition (Lyotard, 1984). The idea that actors make sense of social phenomena by telling stories about them, stories that they use to orient themselves and to guide (or misguide) other actors, is both intuitively plausible and directs theoretical attention to the much-studied hermeneutic mechanisms of enplotment and narratology. However, as Barbara Czarniawska points out, the epistemological status of narratology itself as a method of social inquiry remains an open question and her discussion of the methodological alternatives presented by this technique, which draws heavily on the hermeneutic tradition, pushes the model further than does Abbott (Czarniawska, 2004a).

The first option Czarniawska presents is to treat actors' narratives as partial and sometimes deliberately misleading accounts of 'what is really going on' in the social world. The business of the theorist is to unmask the partial and motivated character of actual narratives, sometimes by telling an alternative story but more often in policy studies by appealing to other methodologies to demonstrate the gap between the stories and an underlying reality (see also Buthe, 2002). The second, equally extreme, option is to undermine the very idea that there are other methodologies that are not also forms of story telling so that there is no underlying reality against which the truth or falsity of particular stories can be checked. The first option is close to the position Buthe, Czarniawska and Abbott have termed 'narrative positivism'. The theorist is trying to 'get the story right' by correctly identifying the causal mechanisms that are actually operating in a world that exists independently of narratives.

The second option, what might be termed 'narrative post-modernism', is less well-adapted to social studies, although it should be noted that it is not necessarily anti-realist and confined to the analysis of the imaginary worlds of literature or philosophy and religion (Edelman, 1964; 1988). This is the model built on the observation that there is a world outside of the narrative itself but the moment we try to describe it we are again telling stories (Foucault, 1972). The shock value 
of the second option has been much exploited in such areas as sociologicallyinspired accounts of science and technology, where scientists are analyzed as (mere) story-tellers (Traweek, 1992; Law, 2000).

More often, however, social theorists have sought some intermediate position between the two extremes, one which brackets metaphysical questions about the existence of a world outside stories and focuses instead on the relations between different stories and between story tellers. In Czarniawska's version of narrative postmodernism, which draws on the popular literary concept of intertextuality, for example, texts speak to other texts. The effect is to create patterns and regularities in interpretation and action which Czarniawska calls 'institutions'. As she puts it: 'the reader is able to see how a text was made $(. .$.$) because reader and writer are both producers and consumers of the$ same set of human institutions' (Czarniawska, 2004a). In recent work, she has focused particularly on the mechanism of framing and the role played by the existing stock of discursive elements that go to make up such a frame (Czarniawska, 2002; 2004c).

Unlike the case with the stochastic model, in narrative positivism one would expect to find lock-step and irreversible patterns of historical development, ones with specific causal patterns related to historical sequencing. In narrative postmodernism, the role of sequencing is much less clear. Presumably, it matters when framing and reframing take place because of the limited stock of 'ideas in good currency' that are available at any particular time (Fischer, 2003). However, in spite of Czarniawska's depiction of frames as 'iron cages' (Czarniawska, 2004b), her characteristically postmodern emphases on reframing and free play tend to undermine any sense that history moves in any kind of specific direction meaning, ironically, that this approach in the end shares much in common with the stochastic model.

\section{Path Dependency: Contingent Sequence Models}

Although less predominant in the social sciences than the stochastic model, as a result of earlier struggles between critical theorists and advocates of more scientistic 'behavioural' methods of social inquiry (Adorno et al, 1976; Almond and Genco, 1977), narrative models remain very popular in fields such as history and literary studies, as well as in the policy sciences (Yanow, 1992). These are not the only models of historical sequencing available to help analyze historical processes such as policy-making, however. For a variety of reasons related to high profile disputes between institutional and other types of economists, one of the best known recent alternatives to stochastic and narrative modes of analysis in the social sciences is the 'path dependency' model (Greener, 2002; 2005).

The contours of the development of the path dependence model in the social sciences are now well known, especially the influence of debates in the economics literature on whether or not it is possible for market transactions to result in 
sub-optimal outcomes as inferior technologies come to be 'locked-in' to specific economic 'trajectories' (Arthur, 1988; 1989; David, 1985; 1986; Liebowitz and Margolis, 1995; 1990). Path dependency in this sense represents a kind of failure to achieve a technically efficient solution that is attributed to any one of a number of factors: to 'network effects' or the ability of inferior technologies to spread and block the adoption of more efficient ones; to 'increasing returns' or the historical accident of the timing of the entry of new technologies into the market place; or to (premature) 'standardization' which can also block the spread of superior technologies. Debates in economics tend to turn on issues of what Liebowitz has called the 'degree' of path dependency, that is, how hard it is to 'turnaround' a sub-optimal process once it is underway (Liebowitz and Margolis, 1995). For some authors turnaround is almost impossible, for others, it is somewhat less difficult to accomplish.

In the social and political realm, the use of the concept of path dependency is less specific than is found in economics and applies to the description of historical processes which observers have found to be highly contingent and inertial in nature. Mahoney outlines the three principal elements of a path dependent model of historical evolution as variations on general narrative precepts. That is: (1) only early events in sequence matter; (2) these early events are contingent; and (3) later events are inertial (Mahoney, 2000). These elements highlight the crucial aspects of path dependent models of historical development that separate this model from narrative analyses and from other models - like process sequencing - which are discussed below: that initial conditions are chance-like, and have a significant influence over the irreversible course of events followed later in the sequence.

Identifying these 'turning points' or 'conjunctures' is thus critical to path dependency analyses of historical processes, although there is significant debate in the literature over exactly what is meant by characterizing an event as 'contingent' (Wilsford, 1985; Abbott, 1997). At its simplest, contingency implies that, although the sequence of events is not a strictly necessary one, predictable from the conditions of the starting point according to general laws, there is nonetheless an explicable pattern which relates one point to another, especially in the early part of the sequence. While a random sequence implies that any event has an equal probability of following from any other, in a contingent sequence each turning point renders the occurrence of the next point more likely until, finally, 'lock in' occurs and a general explanatory principle, such as increasing returns, takes over the work of explanation.

It is important to note that 'contingent' does mean random in this model, even if only with respect to initial starting conditions. So while events located later in a trajectory may be less random, they do not approach the status of 'designed', unless their ad hoc starting point is ignored. Path dependency attributes outcomes to an overall situation in which microcausation and sequence matter and, hence, "deliberate choices" cannot be assumed but require detailed analysis and explanation (List, 2004). 


\section{Punctuated Equilibrium: Process Sequencing Models}

As the extent of contextual embeddedness of social actors increases to the point where we are concerned with apparently irreversible sequences that could not have been other than they were, we find ourselves in the world of the narrative. At the other extreme, where contextual embeddedness is deemed irrelevant and only chance-like conditions prevail, the stochastic model prevails (along with its postmodern narrative equivalent).

Conceptions of history and the analytical methodologies which are associated with them, however, do not line up neatly on a simple spectrum from contextbound to random. This is made clear by the elements and assumptions of the path dependency model which combines narratives' attention to sequence in understanding later trajectories of events, but focusses on contingency and randomness in understanding the causal dynamics of the 'critical junctures' which set those trajectories in motion. These twin dimensions also allow a fourth model of history found in the present-day social sciences do be described, one which provides an alternative conception to both narratives and path dependency of the nature of non-stochastic social processes. In this model, unlike in the stochastic or narrative postmodernist models, sequence does matter. However, unlike the narrative positivist model, it is not concerned with irreversible sequences and, unlike the path dependency model, it does not rely upon random or purely contingent initial conditions to set trajectories in motion. This is the 'process' or 'reactive sequencing' model which conceives of social processes as 'the connections between events in different time periods as reiterated problem solving' (Haydu, 1998). Proponents of this model argue that it has advantages over both the narrative and path dependency models as it 'provides a plausible way to represent and account for historical trajectories; it builds social actors and multiple causal timelines into explanatory accounts; and it offers a richer sense of how earlier outcomes shape later ones' (p. 341).

Rather than connect historical events through stories or paths, proponents of reactive sequencing such as Haydu argue that events can be demarcated on the basis of 'contrasting solutions for recurring problems' (p. 354). That is, 'continuities across temporal cases can be traced in part to enduring problems, while more or less contingent solutions to those problems are seen as reflecting and regenerating the historical individuality of each period' (p. 354).

Based in part on work in evolutionary biology that suggested evolutionary processes proceeded in a stepped or 'punctuated equilibrium' fashion (Gersick, 1991; Eldridge and Gould, 1972; Gould and Eldridge, 1977), this model looks at first sight somewhat like path dependency in its emphasis on turning points and trajectories, and its combination of elements of the stochastic and narrative models. Significantly, however, the model lacks path dependency's emphasis on randomness in the starting points of trajectories and is not wedded to the idea of irreversible trajectories found in narrative positivism. That is, process sequencing stresses not how outcomes at historical switch points are accidents, but how they are firmly 
based or rooted in previous events and thinking as related structural processes of negative and positive feedback affect actor behaviour (Baumgartner and Jones, 2002).

Changes in trajectories in this model are not random or chaotic, but are outgrowths of earlier trajectories. Hence, although process sequencing shares some of the characteristics of the path dependency model, it is not the same. The idea of change occurring as a result of an embedded 'crisis', for example, in the process sequencing model, is not the same as that focusing on random critical juncture found in a typical path dependency explanation. Moreover, this model does not require a uni-directional trajectory following an initial conjuncture, but allows for the kinds of reversals in trajectories identified in the narrative postmodern model as the development of ideas and discourses.

This model has become increasingly popular in fields such as political science as an alternative to path dependent models, providing a better explanation of phenomena such as the creation and development of national and sectoral political institutions as well as political ideas, discourses and paradigms (Lieberman, 2002; Lindner, 2003; Lindner and Rittberger, 2003; Pierson 2000a, 2000b, 2004), and appears to be more consistent with the actual empirical record of changes found in many countries and sectors than is the path dependency model (Dobrowolsky and Saint-Martin, 2005; Morgan and Kubo, 2005; Rico and Costa-Font, 2005).

The key aspect of the stochastic model is its ahistoricism, the notion that sequences do not matter, a point shared with post-modern narratology in the sense that the origin and order of stories is unimportant. The narrative positivist model, on the other hand, emphasizes adaptation within a sequence and the irreversibility of events and trajectories which could not be otherwise than they have been described. In the path dependency model, the key features are the random aspects of critical junctures and hence the possibility of alternative trajectories at early points in a sequence, along with, as in the narrative positivist model, the irreversibility of sequences once 'locked-in'. These contrast with the process sequencing model's emphasis on reiterated problems solving as embedding a new trajectory in a previous one, and the ability of trajectories to shift, and even reverse, direction.

Table 1 below illustrates the key differences between these general models in terms of their assumptions about the direction and origins of historical sequences.

Table I. Conceptions of Historical Change Compared

\begin{tabular}{llll}
\hline & Direction of Sequence & Reversible & Irreversible \\
\hline Origins of Sequence & Contingent/Random & $\begin{array}{l}\text { Stochastic and Narrative } \\
\text { Postmodernist Models }\end{array}$ & Path Dependency \\
& Embedded/Cumulative & Process Sequencing & Narrative Positivism \\
\hline
\end{tabular}




\section{Time as an Institution and a Resource}

The articles in this special issue focus in the main on issues relating to the mapping and explanation of administrative and policy developments over time, drawing on a range of explanatory frameworks as set out in the previous section. By contrast, the article by Goetz (2014) is situated in a political science literature that explores the importance of time rules and temporal regularities in political life. Problems of time pervade political life, whether at the local, regional and national levels of politics or in the international and supranational spheres. Political time is institutionalised, in particular, through rules that govern the length and configuration of terms, mandates and tenures of elected and un-elected officials; through rules that determine when (timing), in what order (sequence), how quickly (speed) and for how long (duration) actions can be taken; and at the level of policy, which is concerned with allocation in time and over time. Formal time rules are complemented by more or less deeply entrenched informal rules, such as those governing the preparation of bills in the ministerial executive or the elaborate time-rules that structure deliberation and decision-taking in parliaments. Time rules and conventions, the time budgets available to political and administrative actors and the typical time horizons with which they operate constitute elements of the institutional setting within which policy-making takes place.

Yet, perhaps surprisingly, the linkages between this time-centred institutional setting and the dynamics of policy-making are rarely systematically explored. With explicit reference to political time in the EU, Goetz and Meyer-Sahling (2009) have suggested to distinguish between a polity dimension of political time: terms, mandates, tenures, time budgets and time horizons; a politics dimension, which is concerned with rules relating to timing, sequencing, speed and duration in decision-making; and a policy dimension, which is about temporal policy features, such as the intertemporal distribution of costs and benefits of major policies. Drawing on actor-centred institutionalism, they suggest that political time should be understood both as an institution and as a resource for (and, by implication, a constraint on) actors in political decision-making. Actor-centred institutionalism bases its explanations on rational expectations, but acknowledges the institutional environment of exchanges between actors as being fundamental. It describes institutions as 'a system of rules that structure the courses of actions that a set of actors may chose,' and these rules may be formal or consist of 'social norms that actors will generally respect and whose violation will be sanctioned by loss of reputation, social disapproval, withdrawal of cooperation and rewards, or even ostracism.' (Scharpf 1997: 38). Accusations of 'bad timing,' 'undue haste,' or 'playing for time' often result from perceived violations of such social norms (Goodin 1998). Importantly, institutions so understood 'define repertoires of more or less acceptable courses of action that will leave considerable scope for the strategic and tactical choices of purposeful actors' (Scharpf 1997: 42). It is when making those choices that time can also be an important resource, as actors are able to use time tactics, such as intentional delay, as discussed by Pollitt (2008). 


\section{Outlook}

The special issue that this article introduces aims to further the debate about time in administration and policy and also an appreciation of the methodological issues it raises. In particular, the articles highlight historical accounts of time, organisations and policies and the linkages between temporal discretion, time tactics and the capacity for substantive goal attainment. The articles address conceptual, methodological and epistemological issues related to time, politics, administration and public policy, and critically examine the literature in the field while so doing. Three of the articles contained in this special issue focus on tracing and explaining developments over time, including Newman and Howlett (2014) who examine temporal patterns in regulatory development; Studlar and Cairney (2014) who explain policy change relating to tobacco control; and Borghetto (2014) who explores the temporal trajectories of Italian law-making by means of sequence analysis. The article by Tucker (2014) explores methodological issues surrounding the visualization of timescapes in the comparative study of the American states. The final contribution, by Goetz (2014), analyses important temporal features of the European Commission at political and administrative levels and how they are linked to the distribution of power. Taken together, the articles underline how work in public administration and public policy can benefit from paying systematic attention to time, temporality and timescapes.

\section{Acknowledgements}

A first version of this paper was presented at the workshop on 'Time, Temporality and Timescapes in Politics and Policy', 40th ECPR Joint Sessions of Workshops, Antwerp, April 2012. We wish to thank the participants of the workshop for their helpful comments and suggestions. We also thank the two anonymous referees of the journal for their constructive comments.

\section{References}

Abbott A (1990) Conceptions of time and events in social science methods. Historical Methods 23(4): 140-151.

Abbott A (1992) From causes to events: notes on narrative positivism'. Sociological Methods and Research 20(4): 428-455.

Abbott Andrew (1997) On the concept of turning point. Comparative Social Research 16: 85-105.

Abbott Andrew (1988) Transcending General Linear Reality.” Sociological Theory 6(1988): 169-186.

Abbott Andrew (2001) Time Matters: On Theory and Method. Chicago: University of Chicago Press.

Adam B (1995) Timewatch: The Social Analysis of Time. Cambridge, UK: Polity Press.

Adam B (1998) Timescapes of Modernity. London: Routledge.

Adam B (2004) Time. Cambridge, UK: Polity Press.

Adam B (2008) 'Of Timescapes, Futurescapes and Timeprints', Paper presented at Lueneburg University, 17 June 2008. 
Adorno TW, Albert H, Dahrendorf R, Habermas J, Pilot H and Popper KR (1976) The Positivist Dispute in German Sociology. London: Heinemann.

Almond Gabriel A and Genco Stephen J (1977) Clouds, clocks and the study of politics. World Politics 29: 489-522.

Aminzade Ronald (1992) Historical Sociology and Time. Sociological Methods and Research 20(4): 456-480.

Arthur W Brian (1989) Competing technologies, increasing returns, and lock-in by historical events. The Economic Journal 99: 116-131.

Arthur W Brian (1988) 'Self-reinforcing Mechanisms in Economics'. In: Anderson PW, Arrow KJ and Pines D (eds) The Economy as an Evolving Complex System. Redwood City: Addison Wesley.

Bartolini S (2005) Restructuring Europe. Oxford: OUP.

Baumgartner Frank R and Jones Bryan D (2002) 'Positive and Negative Feedback in Politics.' In: Baumgartner FR and Jones BD (eds) Policy Dynamics. Chicago: University of Chicago Press.

Borghetto Enrico (2014) Legislative processes as sequences: Exploring temporal trajectories of Italian law-making by means of sequence analysis. International Review of Administrative Sciences 80(3): 553-576.

Brée DS, Feddag A and Pratt I (1993) Towards a formalization of the semantics of some temporal prepositions. Time \& Society 2(2): 219-240.

Buthe Tim (2002) Taking temporarility seriously: modeling history and the use of narratives as evidence. American Political Science Review 96(3): 481-493.

Czarniawska Barbara (1998) A Narrative Approach to Organization Studies. London: SAGE.

Czarniawska Barbara (2004a) 'The Uses of Narrative in Social Science Research'. In: Hardy Melissa and Bryman Alan (eds) Handbook of Data Analysis. London: SAGE, pp. 649-666.

Czarniawska Barbara (2004b) Narratives in Social Science Research. London: SAGE.

Czarniawska Barbara (2004c) On time, space, and action nets. Organization 11(4): 773-791.

David PA (1985) Clio and the Economics of QWERTY. The American Economic Review 75(2): 332-337.

David PA (1986) Understanding the Economics of QWERTY: The Necessity of History. Economic History and the Modern Economist. London: Basil Blackwell, pp. 30-49.

Dobrowolsky Alexandra and Saint-Martin Denis (2005) Agency, actors and change in a child-focused future 'path dependency' problematized. Commonwealth and Comparative Politics 43(1): 1-33.

Edelman Murray (1964) The Symbolic Uses of Politics. Chicago: University of Illinois Press.

Edelman Murray J (1988) Constructing the Political Spectacle. Chicago: University of Chicago Press.

Elchardus M (1988) The rediscovery of Chronos: the new role of time in sociolocical theory. International Sociology 3(1): 35-59.

Eldredge N and Gould SJ (1972) 'Punctuated Equilibria: An Alternative to Phyletic Gradualism'. In: Schopf TJM (ed.) Models in Paleobiology. San Francisco: Freeman, Cooper \& Co, pp. 82-115.

Fischer Frank (2003) Reframing Public Policy: Discursive Politics and Deliberative Practices. Oxford: Oxford University Press.

Foucault Michel (1972) 'The Discourse on Language'. in The Archaeology of Knowledge. New York: Pantheon, pp. 215-235.

Gadamer Hans-Georg (1989) Truth and Method. New York: Crossroad. 
Gersick CJG (1991) Revolutionary change theories: a multilevel exploration of the punctuated equilibrium paradigm. Academy of Management Review 16(1): 10-36.

Goetz KH (2014) Time and power in the European Commission administration. International Review of Administrative Sciences 80(3): 577-596.

Goetz KH and Mayer-Sahling J-H (2009) Political time in the EU: dimensions, perspectives. theories. Journal of European Public Policy 16(2): 180-201.

Goodin R (1998) Keeping political time: the rhythms of democracy. Internaitonal Political Science Review 19(1): 39-54.

Gould Stephen Jay and Niles Eldredge (1977) Punctuated equilibria: the tempo and mode of evolution reconsidered. Paleobiology 3: 115-151.

Greener Ian (2005) The potential of path dependence in political studies. Politics 25(1): $62-72$.

Greener Ian (2002) Theorizing path-dependency: how does history come to matter in organizations? Management Decision 40(5/6): 614-619.

Griffin Larry (1992) Temporality, Events and Explanation in Historical Sociology. Sociological Methods and Research 20(4): 403-427.

Griffin Larry J (1993) Narrative, event-structure analysis, and causal interpretation in historical sociology. American Journal of Sociology 98(5): 1094-1133.

Hall PA and Taylor RCR (1996) Political Science and the Three New Institutionalisms. Political Studies 44(5): 936-957.

Haydu Jeffrey (1998) Making use of the past: time periods as cases to compare and as sequences of problem solving. American Journal of Sociology 104(2): 339-371.

Howlett $\mathbf{M}$ and Rayner $\mathbf{J}$ (2006) Understanding the historical turn in the policy sciences: a critique of stochastic, narrative, path dependency and process-sequencing models of policy-making over time. Policy Sciences 39(1): 1-18.

Ihde Don (1974) The Conflict of Interpretations: Essays in Hermeneutics/Paul Ricoeur. Evanston: Northwestern University Press.

Kato Junko (1996) Review Article: Institutions and rationality in politics - three varieties of neo-institutionalists. British Journal of Political Science 26: 553-582.

Kay Adrian (2005) A Critique of the Use of Path Dependency in Policy Studies. Public Administration 83(3): 553-571.

Law John (2000) On the subject of the object: narrative, technology, and interpellation. Configurations 8(1): 1-29.

Lieberman Evan S (2001) Causal inference in historical institutional analysis: a specification of periodization strategies. Comparative Political Studies 34(9): 1011-1035.

Lieberman Robert C (2002) Ideas, institutions and political order: explaining political change. American Political Science Review 96(4): 697-712.

Liebowitz S and Margolis SE (1995) Policy and path dependence: from QWERTY to Windows 95. Regulation 18: 33-41.

Liebowitz SJ and Margolis SE (1990) The fable of the keys. Journal of Law and Economics 33: $1-25$.

Liebowitz SJ and Margolis SE (1995) Path dependence, lock-in, and history. Journal of Law, Economics and Organization 11(1): 205-225.

Lindner Johannes and Berthold Rittberger (2003) The creation, interpretation and contestation of institutions - revisiting historical institutionalism. Journal of Common Market Studies 41(3): 445-473.

Lindner Johannes (2003) Institutional Stability and Change: Two Sides of the Same Coin. Journal of European Public Policy 10(6): 912-935. 
Linz J (1998) 'Democracy's time constraints'. International Political Science Review' 19(1): $19-37$.

List Christian (2004) A model of path-dependence in decisions over multiple propositions. American Political Science Review 98(3): 495-513.

Lyotard Jean-François (1984) The Postmodern Condition: A Report on Knowledge. Minneapolis: University of Minnesota Press.

Mahoney J (2000) Path dependence in historical sociology'. Theory and Society 29(4): 507-548.

Mahoney James and Dietrich Rueschemeyer (eds) (2003) Comparative Historical Analysis in the Social Sciences. Cambridge: Cambridge University Press.

Mayer-Sahling J.-H and Goetz KH (2009) The EU timescape: from notion to research agenda. Journal of European Public Policy 16(2): 325-336.

Morgan Glenn and Izuma Kubo (2005) Beyond path dependency? Constructing new models for institutional change: the case of capital markets in Japan. Socio-Economic Review 3: $55-82$.

Newman Joshua and Michael Howlett (2014) Regulation and time: temporal patterns in regulatory development. International Review of Administrative Sciences 80.

Nowotny H (1989) Eigenzeit: Entstehung und Strukturierung eines Zeitgefühls. Frankfurt a M: Campus.

Nowotny H (1992) Time and social theory. Time \& Society 1(3): 421-454.

Ospina Sonia M and Jennifer Dodge (2005) It's about time: catching method up to meaning - the usefulness of narrative inquiry in public administration research. Public Administration Review 65(2): 143-157.

Pierson P (2000a) Increasing returns, path dependence, and the study of politics. American Political Science Review 94(2): 251-267.

Pierson P (2000b) Not just what, but when: timing and sequence in political processes. Studies in American Political Development 14(1): 72-92.

Pierson P (2004) Politics in Time: History, Institutions, and Social Analysis. Princeton: Princeton University Press.

Pollitt C (2008) Time, Policy, Management: Governing with the Past. Oxford: Oxford University Press.

Raadschelders Jos CN (1998) Evolution, institutional analysis and path dependency: an administrative-history perspective on fashionable approaches and concepts. International Review of Administrative Sciences 64(4): 565-582.

Rico Ana and Joan Costa-Font (2005) Power rather than path dependency? The dynamics of institutional change under Health Care Federalism. Journal of Health Politics, Policy and Law 30(1-2): 231-252.

Riescher G (1994) Zeit und Politik. Baden-Baden: Nomos Verlagsgesellschaft.

Riescher G (1997) Parlamentarische Zeitstrukturemn zwischen geschichtlichen Traditionslinien und moderner Funktionalitäl. Zeitschrift für Parlamentsfragen 44: $101-115$.

Roe E (1994) Narrative Policy Analysis: Theory and Practice. Durham: Duke University Press.

Sabatier P (1993) 'Policy Change Over A Decade or More'. In: Sabatier PA and JenkinsSmith HC (eds) Policy Change and Learning: An Advocacy Coalition Approach. Boulder: Westview, pp. 13-40.

Saldana J (2003) Longitudinal Qualitative Research: Analyzing Change Through Time. New York: Altamira. 
Scharpf FW (1997) Games Real Actors Play: Actor-Centered Institutionalism in Policy Research. Boulder: Westview Press.

Schedler A (2007) 'Mapping Contingency'. In: Shapiro I and Bedi S (eds) Political Contingency: Studying the Unexpected, the Accidental and the Unforeseen. New York: New York University Press, pp. 54-78.

Schedler A and Santiso J (1998) Democracy and time: an invitation. International Political Science Review 19(1): 5-18.

Schmitter P C and Santiso J (1998) 'Three temporal dimensions to the consolidation of democracy'. International Political Science Review 19(1): 69-92.

Schwartz, Herman. 'Down the Wrong Path: Path Dependence, Increasing Returns, and Historical Institutionalism.' Available online at http://www.people.virginia.edu/ $\sim$ hms2f/Path.pdf (accessed 15.07.14).

Simsa R (1996) Wem gehört die Zeit? Hierarchie und Zeit in Gesellschaft und Organisationen. Frankfurt a. M: Campus.

Skowronek S (1993) The Politics Presidents Make: Leadership from John Adams to George Bush. Cambridge, MA: Belknap Press of Harvard University Press.

Skowronek S (2008) Presidential Leadership in Political Time: Reprise and Reappraisal. Lawrence: University Press of Kansas.

Somers Margaret R (1996) 'Where is Sociology after the Historic Turn? Knowledge Cultures, Narrativity, and Historical Epistemologies'. In: McDonald T J (ed.) The Historic Turn in the Human Sciences. Ann Arbor: The University of Michigan Press, pp. 53-89.

Steinmo Sven, Kathleen Thelen and Frank Longstreth (1992) Structuring Politics: Historical Institutionalism in Comparative Analysis. Cambridge: Cambridge University Press.

Stinchcombe Arthur (1968) Constructing Social Theories. New York: Harcourt, Brace, and World.

Stone D (1999) Learning lessons and transferring policy across time, space and disciplines. Politics 19(1): 51-59.

Studlar Donley T and Cairney P (2014) Conceptualizing punctuated and non-punctuated policy change: Tobacco control in comparative perspective. International Review of Administrative Sciences 80.

Thelen K (2000) 'Timing and temporaiity in the analysis of institutional evolution and change'. Studies in American Political Development 14(1): 101-108.

Thelen Kathleen (2003) 'How Institutions Evolve: Insights from Comparative Historical Analysis'. In: Mahoney J and Rueschemeyer D (eds) Comparative Historical Analysis in the Social Sciences. Cambridge: Cambridge University Press, pp. 208-240.

Traweek Sharon (1992) Border Crossings: Narrative Strategies in Science Studies and among Physicists in Tsukuba Science City, Japan. In: Andrew Pickering (ed.) Science as Practice and Culture. University of Chicago Press, pp. 429-466.

True J L (2000) 'Avalanches and Incrementalism: Making Policy and Budgets in the United States'. American Review of Public Administration 30(1): 3-18.

True J L, Jones B D and Baumgartner F R (1999) 'Punctuated-Equilibrium Theory: Explaining Stability and Change in American Policymaking'. In: Sabatier P A (ed.) Theories of the Policy Process. Boulder: Westview Press, pp. 97-115.

Tucker, Harvey J (2014) "Visualizing timescape issues in the comparative study of the American States", International Review of Administrative Sciences, 80.

Tsebelis G (2002) Veto Players: How Political Institutions Work. Princeton: Princeton Press. 
Wilsford D (1995) The conjoncture of ideas and interests. Comparative Political Studies 18(3): 357-372.

Wilsford D (1994) Path dependency, or why history makes it difficult but not impossible to reform health care systems in a big way. Journal of Public Policy 14(3): 251-284.

Wood B D and Doan A (2003) 'The Politics of Problem Definition: Applying and Testing Threshold Models'. American Journal of Political Science 47(4): 640-653.

Yanow Dvora (1992) Silences in public policy discourse: organizational and policy myths. Journal of Public Administration Research and Theory 2(4): 399-423.

Zahariadis N (2007) 'The Multiple Streams Framework: Structures, Limitations, Prospects'. In: Sabatier P (ed.) Theories of the Policy Process, 2nd ed. Boulder: Westview Press, pp. $65-92$.

Michael Howlett is Burnaby Mountain Chair in the Department of Political Science at Simon Fraser University and Yong Pung How Chair Professor in the Lee Kuan Yew School of Public Policy at the National University of Singapore. He specializes in public policy analysis, political economy, and resource and environmental policy. He is the author most recently of Canadian Public Policy (University of Toronto Press 2013) and Designing Public Policy (Routledge 2011), co-editor of Regulating Next Generation Agri-Food Bio-Technologies (Routledge 2012), and The Routledge Handbook of Public Policy (2013).

Klaus H. Goetz holds the Chair in Political Systems and European Integration at the University of Munich. He previously taught at LSE and the University of Potsdam. He specialises in comparative government, public policy and public administration. He currently works on two research projects funded by the German Research Foundation on staggered membership renewal in second chambers and on budgeting in international administrations, respectively (see www. politicaltime.eu). He has been co-editor of West European Politics since 2000. 